\title{
Assessing the applicability of the Revised Universal Soil Loss Equation (RUSLE) to Irish Catchments
}

\author{
A. RYMSZEWICZ ${ }^{1}$, E. MOCKLER ${ }^{1}$, J. O'SULLIVAN ${ }^{1}$, M. BRUEN ${ }^{1}$, J. TURNER ${ }^{2}$, \\ E. CONROY ${ }^{3}$, M. KELLY-QUINN ${ }^{3}$, J. HARRINGTON ${ }^{4} \&$ D. LAWLER $^{5}$ \\ 1 UCD Dooge Centre for Water Resources Research, School of Civil, Structural and Environmental Engineering, \\ University College Dublin \\ anna.rymszewicz@ucdconnect.ie \\ 2 School of Geography, Planning and Environmental Policy, University College Dublin, Ireland \\ 3 School of Biology and Environmental Science, University College Dublin, Ireland \\ 4 School of Building, Civil \& Environmental Engineering, Cork Institute of Technology, Ireland \\ 5 Centre for Agroecology, Water and Resilience, Coventry University, UK
}

\begin{abstract}
Elevated suspended sediment concentrations in fluvial environments have important implications for system ecology and even small concentrations may have serious consequences for sensitive ecosystems or organisms, such as freshwater pearl mussels (Margaritifera margaritifera). Informed decision making is therefore required for land managers to understand and control soil erosion and sediment delivery to the river network. However, given that monitoring of sediment fluxes requires financial and human resources which are often limited at a national scale, sediment mobilisation and delivery models are commonly used for sediment yield estimation and management. The Revised Universal Soil Loss Equation (RUSLE) is the most widely used model for overland flow erosion and can, when combined with a sediment delivery ratio (SDR), provide reasonable sediment load estimations for a catchment. This paper presents RUSLE factors established from extant GIS and rainfall datasets that are incorporated into a flexible catchment modelling approach. We believe that this is the first time that results from a RUSLE application at a national scale are tested against measured sediment yield values available from Ireland. An initial assessment of RUSLE applied to Irish conditions indicates an overestimation of modelled sediment yield values for most of the selected catchments. Improved methods for model and SDR factors estimation are needed to account for Irish conditions and catchment characteristics. Nonetheless, validation and testing of the model in this study using observed values is an important step towards more effective sediment yield modelling tools for nationwide applications.
\end{abstract}

Key words Ireland; soil loss modelling; RUSLE; sediment yield; validation

\section{INTRODUCTION}

Fine sediments are of particular interest for catchment management, because excessive concentrations can have detrimental impacts on freshwater biota. When suspended within the water column, sediments reduce light penetration affecting primary and higher trophic level production and can adversely affect fish populations by causing elevated levels of stress and physical damage to organs, as well as reducing dissolved oxygen levels and water quality (Kemp et al. 2011). Fine sediments also play an important role in the transfer of nutrients, heavy metals and other pollutants (e.g. Owens et al. 2001), through sorption processes to fine grained sediments (typically $<63 \mu \mathrm{m}$ ). When deposited, sediments can adversely affect the richness and density of macroinvertebrate communities (Jones et al. 2012), and siltation into coarse gravels and the crucial Hyporheic Zone (Lawler et al. 2009) may result in local deoxygenation and consequently degradation of important habitats such as fish spawning grounds (e.g. Heywood \& Walling, 2007) and freshwater pearl mussel (Margaritifera margaritifera) beds.

The European Water Framework Directive (WFD) (2000/60/EC) does not currently provide adequate guidelines for standards of suspended or deposited sediments. The annual average suspended sediment concentration (SSC) limit of $25 \mathrm{mg} \mathrm{L}^{-1}$ under the EU Freshwater Fish Directive (2006/44/EC) does not consider high temporal and spatial variations of sediment transport across a range of catchment characteristics (e.g. Lawler et al. 2006), or consider complex and variable biological response to fine sediments in fluvial systems (Bilotta \& Brazier, 2008; Collins et al. 2011; Kemp et al. 2011).

Sediment flux data are limited to a few studies for Ireland, showing sediment yields of between $0.03-0.44$ tonnes ha $^{-1}$ year $^{-1}$ (Table 1). Although these values are low compared to those 
reported for other European countries (Vanmaercke et al. 2011), SSC levels as high as $117 \mathrm{mg} \mathrm{L}^{-1}$ and $590 \mathrm{mg} \mathrm{L}^{-1}$ have been recorded during flood periods (Harrington \& Harrington, 2013) and values above the $25 \mathrm{mg} \mathrm{L}^{-1}$ guideline have been reported in Irish catchments, including periods of potential salmon migration and spawning (Thompson et al. 2014). Given the presence of siltationsensitive habitats, including Atlantic salmon spawning grounds and freshwater pearl mussel beds (NPWS, 2008), Ireland faces a challenge to set new guidelines for sediment regimes and limits. This requires high resolution monitoring of suspended and deposited sediment loading that must link to impacts on the ecology of freshwater biota. Although research is currently underway in Ireland under academic institutions and state agencies such as the Environmental Protection Agency (EPA), Teagasc, Marine Institute, Office of Public Work (OPW), logistic and economic constraints mean that these investigations are limited to a low number of catchments. Empirical sediment data may therefore be insufficient for decision-making purposes and complementary support tools, such as sediment mobilisation and delivery models will be necessary for more appropriate sediment yield estimation at the national scale.

Table 1 Suspended sediment yield data in Ireland.

\begin{tabular}{lllll}
\hline Catchment & $\begin{array}{l}\text { Area } \\
\left(\mathrm{km}^{2}\right)\end{array}$ & $\begin{array}{l}\text { Sediment yield* } \\
\left(\text { tonnes } \mathrm{ha}^{-1} \text { year }^{-1}\right)\end{array}$ & Study period & Reference \\
\hline Mount Stewart & 7.52 & 0.067 & Sept 2011-Sept 2012 & Thompson et al. 2014 \\
Dunleer & 9.4 & 0.15 & Oct 2009-Sept 2010 & Melland et al. 2010 \\
& 9.4 & 0.135 & Oct 2010-Sept 2011 & Melland et al. 2010 \\
Castledockrell & 11 & 0.177 & Oct 2009-Sept 2010 & Melland et al. 2010 \\
& 11 & 0.031 & Oct 2010-Sept 2011 & Melland et al. 2010 \\
Dripsey & 15.24 & 0.161 & Jan 2002-Dec 2002 & Kiely et al. 2007 \\
& 15.24 & 0.098 & Jan 2003-Dec 2003 & Kiely et al. 2007 \\
Glenamong & 17.91 & 0.16 & 2001 & May et al. 2005 \\
Mattock & 20.96 & 0.44 & Nov 2011-Nov 2012 & Thompson et al. 2014 \\
Clarianna & 29.8 & 0.085 & Jan 2002-Dec 2002 & Kiely et al. 2007 \\
The Oona & 84.5 & 0.29 & Oct 2000-Sept 2002 & Kiely et al. 2007 \\
& 84.5 & 0.41 & Jan 2002-Dec 2002 & Kiely et al. 2007 \\
Owenabue & 103 & 0.256 & Sept 2009-Sept 2010 & Harrington \& Harrington 2013 \\
Bandon & 424 & 0.142 & Feb 2010-Feb 2011 & Harrington \& Harrington 2013 \\
\hline
\end{tabular}

*When sediment flux was reported in the study it was converted into sediment yield units by dividing flux values by catchment size. Other units like $\mathrm{kg} \mathrm{ha}^{-1} \mathrm{year}^{-1}$ or tonnes $\mathrm{km}^{-2}$ year-1 were also converted to uniform units of tonnes ha $^{-1}$ year $^{-1}$.

The Universal Soil Loss Equation (USLE) (Wischmeier \& Smith, 1978) and the more recent Revised Universal Soil Loss Equation (RUSLE) (Renard et al. 1997) are widely used to model erosion by overland flow. Although these models were originally designed to estimate soil loss on a field-plot scale, they can be combined with the concept of the sediment delivery ratio (SDR) (Walling, 1983) to provide sediment load estimation at a catchment scale, although not without problems (e.g. Parsons et al. 2008; Kinnell 2010). Many non-point source pollution catchmentscale models base overland sediment transport modelling on the USLE and its variations (Borah \& Bera, 2003), mainly due to its simplicity in application. In Ireland, the USLE was previously applied to the small Burrishoole catchment using empirical data for a sub-catchment (the Glenamong) to calibrate the model (May \& Place 2005). The RUSLE has also been applied at the national scale to estimate soil erosion and, combined with a Sediment Delivery Distributed (SEDD) model, was used to estimate sediment yield for the Mallow catchment (He, 2010). The nationwide application of RUSLE, however, has thus far lacked validation against measured data that would better confirm its suitability for Irish conditions.

This study aims to investigate the applicability of the RUSLE to Irish catchments and to assess its utility as a national sediment yield assessment tool. The study provides a comparison of modelled sediment yield values to those observed in selected Irish catchments (Fig. 1), which represents an important new step towards assessing the wider application of RUSLE in Ireland. 

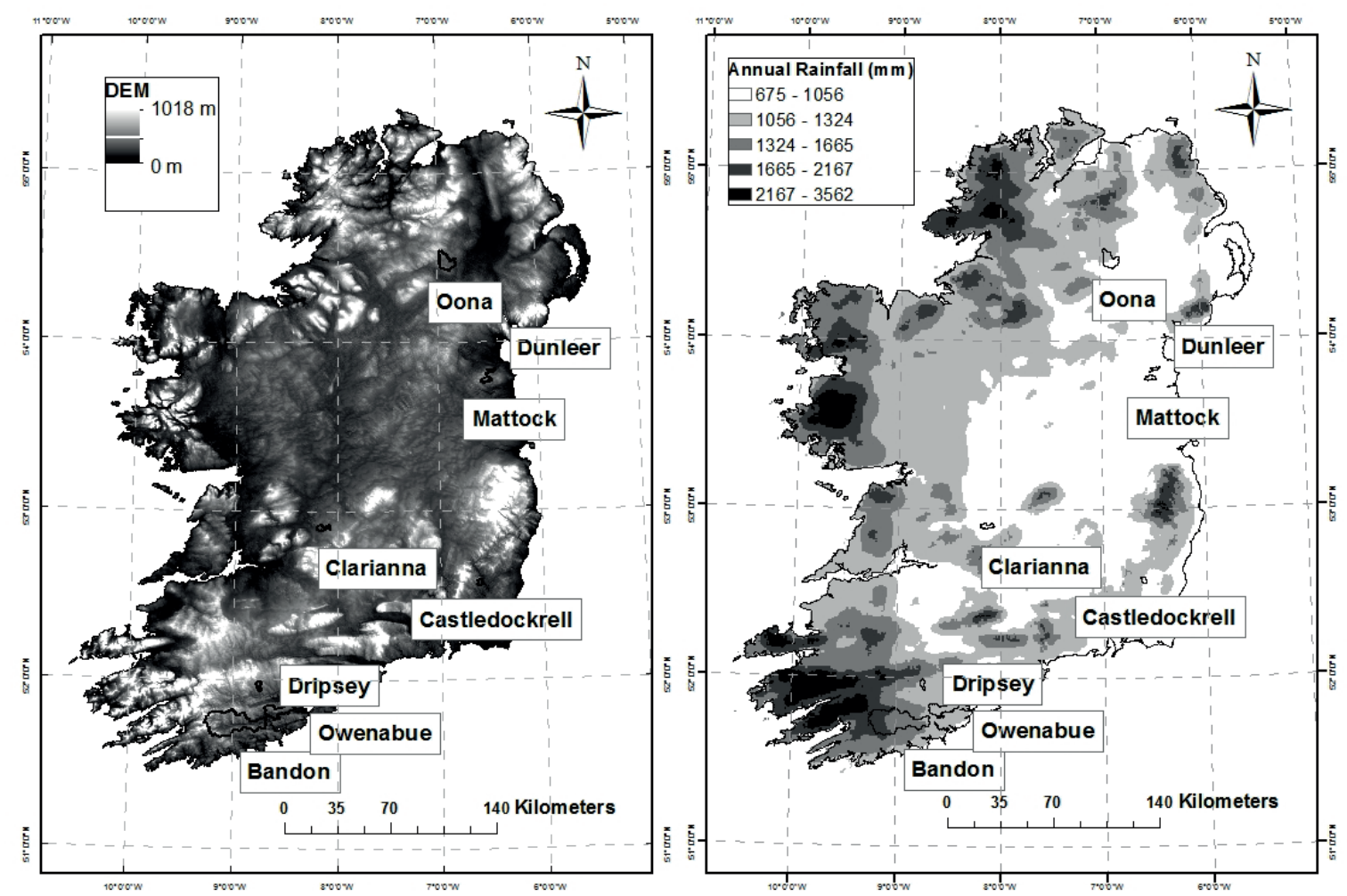

Fig. 1 Study catchments and corresponding topography and average annual precipitation pattern (data sources: EPA and Met Éireann). Note that both average annual precipitation, and rainfall seasonality, increases from east to west across Ireland (Walsh \& Lawler, 1981).

\section{MATERIALS AND METHODS}

RUSLE and SDR were applied to eight Irish catchments and compared to 12 measured annual sediment yield values. Study catchments were delineated using digital elevation model (DEM) datasets based on the information provided in the corresponding studies, and RUSLE factors were derived from available rainfall data and GIS datasets.

RUSLE estimates mean annual soil loss (SL) according to:

$$
A=R \cdot K \cdot L S \cdot C \cdot P
$$

where $A=$ mean annual soil loss (tonnes ha- ${ }^{-1}$ year $\left.^{-1}\right), R=$ the rainfall erosivity factor (MJ $\mathrm{mm} \mathrm{ha}^{-1}$ $\mathrm{h}^{-1}$ year $\left.{ }^{-1}\right), K=$ the soil erodibility factor (tonnes $\mathrm{h} \mathrm{MJ}^{-1} \mathrm{~mm}^{-1}$ ), $L S=$ the topographic factor (dimensionless), $C=$ the crop management factor (dimensionless), $P=$ the erosion control practice factor (dimensionless). The details of the factors and how they are estimated are discussed in Renard et al. (1997), and an example of the approach is provided in Ranzi et al. (2012).

\section{Rainfall erosivity factor $(R)$}

Data with one hour, 30 minute, 15 minute and 1 minute resolution at the nearest meteorological station to the study catchment were used to calculate the individual annual $R$ factor specific to the corresponding study period (data source: Met Éireann, http://www.met.ie/). Rainfall data were converted to $10 \mathrm{~min}$ intervals and the $R$ factor was calculated based on storm $\mathrm{EI}_{30}$ values (product of storm kinetic energy and the maximum 30-min intensity), using the algorithm implemented in C programming language available from the European Soil Portal - Soil Data Information System (Meusburger et al. 2012; Panagos et al. 2012).

Calculations were only performed on potentially significant erosive events, using criteria provided by Renard et al. (1997), where storms of at least $12.7 \mathrm{~mm}$ total precipitation, or smaller storms with at least $6.35 \mathrm{~mm}$ rain falling in $15 \mathrm{~min}$, were considered. Precipitation of less than $1.27 \mathrm{~mm}$ over 6 hours was used to divide a longer storm into two individual storms. 


\section{Soil erodibility factor $(K)$}

To estimate the $K$ factor, a soil erodibility GIS map at 500-m resolution was used. This was prepared with the Land Use/Cover Area frame Survey (LUCAS) soil survey data available for 25 Member States of the European Union (Panagos et al. 2014).

\section{Slope length and steepness factor $(L S)$}

Taking into consideration the complexity of algorithms for quantifying the $L S$ factor and the need for the ease of application for a national scale modelling tool, it was proposed to simplify the estimation of this factor and link it to the national DEM and sub-basins drainage density characteristics by relating the steepness of the catchment to the distance to the nearest stream.

The proposed $L S$ factor is calculated as:

$$
L S=S / \operatorname{drain} D
$$

where $S=$ the average gradient of the slope (degrees) and $\operatorname{drain} D=$ the drainage density factor, calculated for each sub-basin as:

$$
\text { drainD = strLength / area }
$$

where strLength $=$ length of stream network $(\mathrm{km})$, area $=$ area of sub-basin $\left(\mathrm{km}^{2}\right)$.

The $L S$ factor was calculated for each study catchment using equation (2) and compared to average $L S$ value estimated for each catchment using the upslope contributing area (UCA) method, described by Mitasova et al.(1996) and Mitasova et al.(2010 [online]), thus:

$$
L S=(m+1) \cdot\left[U C A / a_{0}\right]^{m} \cdot\left[\sin b / b_{0}\right]^{n}
$$

where $U C A$ is upslope contributing area per unit contour width, $b$ [degrees] is the slope angle, $m=$ $0.4-0.6, n=1.0-1.4, a_{0}=$ is the length of $22.1 \mathrm{~m}, b_{0}=$ is the slope of the standard USLE plot at 0.09 or $9 \%$. In this study values of $m=0.6$ and $n=1.3$ were used (Moore \& Wilson 1992). Equation (4) incorporated into the GIS Raster Calculator tool is expressed as:

$$
\text { Power }((\text { flow_acc } \cdot \text { cell_res }) / 22.13,0.6) \cdot \text { Power }(\sin (\text { slope } \cdot 0.01745) / 0.09,1.3) \cdot 1.6
$$

This method requires a flow accumulation $\left(f l o w \_a c c\right)$ grid which can be derived from a DEM, and in this study it was derived and obtained from national EPA datasets at $20 \mathrm{~m}$ resolution.

\section{Vegetation cover and crop management factor $(C)$}

The $C$ factor values were assigned to each land use class for the CORINE 2006 land cover GIS map, based on values found in the literature. The $C$ factor for all arable areas was set to a longterm average value of 0.3 , pasture areas to 0.01 and forest to 0.001 . These values have been most widely employed in other studies (e.g. Bakker et al. 2008). Peat land was assigned a value of 0.56 , which has been previously used for wetland land use in the global soil erosion estimate study (Pham et al. 2001).

\section{Support practice factor $(P)$}

As there is no significant support practice for arable land in Ireland (and information on subsurface drainage is not available) this factor is assumed to be equal to 1 for Irish catchments.

\section{Sediment delivery ratio (SDR)}

In this study a simple relation (based on studies from 300 watersheds throughout the world) between catchment size and SDR by Vanoni (1975) was chosen:

$$
S D R=0.42 C A^{-0.125}
$$

where $C A=$ catchment drainage area in square miles. 


\section{RESULTS AND DISCUSSION}

Average RUSLE factor values and modelled annual sediment yields for study catchments are presented in Tables 2 and 3, respectively. Results show an overestimated sediment yield assessment for five catchments (Dunleer, Castledockrell, Dripsey, Owenabue and Bandon), whereas predicted values for the Oona and Mattock rivers are about 50\% lower than the observed values. The Clarianna sediment yield modelled with the $L S_{2}$ factor (using topographic factor calculated with equation (4), see Table 2) produced a close correspondence to the measured value.

The biggest percentage differences between modelled and observed sediment yield values were found in two small catchments, namely the Dripsey and Castledockrell. These high values are mainly the result of a high $R$ factor (Dripsey) and high $L S$ factor (Castledockrell). Slightly smaller overestimation of sediment yield found in the Bandon and Owenabue catchments can be attributed to the relatively large catchment areas. Subdividing these catchments into sub-basin scales may decrease high values of $L S$ found in these catchments and consequently improve sediment yield prediction.

Table 2 Estimates of mean RUSLE factors and SDR for Irish catchments.

\begin{tabular}{lllllll}
\hline Catchment & $R$ & $K$ & $L S_{1}$ & $L S_{2}$ & $C$ & $S D R$ \\
\hline Dunleer (year 1) & 143.5 & 0.0301 & 1.72 & 2.54 & 0.1355 & 0.36 \\
Dunleer (year 2) & 116 & 0.0301 & 1.72 & 2.54 & 0.1355 & 0.36 \\
Castledockrell (year 1) & 364.6 & 0.0313 & 3.06 & 4.08 & 0.2119 & 0.35 \\
Castledockrell (year 2) & 96.2 & 0.0313 & 3.06 & 4.08 & 0.2119 & 0.35 \\
Dripsey (year 1) & 726.3 & 0.0290 & 3.15 & 2.83 & 0.1140 & 0.34 \\
Dripsey (year 2) & 410.9 & 0.0290 & 3.15 & 2.83 & 0.1140 & 0.34 \\
Mattock & 138 & 0.0273 & 3.41 & 3.87 & 0.0417 & 0.32 \\
Clarianna & 107.3 & 0.0268 & 2.84 & 1.18 & 0.0782 & 0.31 \\
The Oona (year 1) & 121.4 & 0.0238 & 3.49 & - & 0.0471 & 0.27 \\
The Oona (year 2) & 182.7 & 0.0238 & 3.49 & - & 0.0471 & 0.27 \\
Owenabue & 378.3 & 0.0301 & 3.85 & 4.4 & 0.1002 & 0.27 \\
Bandon & 295.1 & 0.0279 & 4.22 & 3.31 & 0.0857 & 0.22 \\
\hline$R$
\end{tabular}

$R$ - Rainfall erosivity factor (MJ mm ha ${ }^{-1} \mathrm{~h}^{-1}$ year ${ }^{-1}$ ), $K$ - Soil erodibility (tonnes $\mathrm{h} \mathrm{MJ}^{-1} \mathrm{~mm}^{-1}$ ),

$L S_{1}$ - topographic factor calculated with equation (2), $L S_{2}$ - topographic factor calculated with equation (4), $C-$ the crop management factor, $S D R$ - sediment delivery ratio

Table 3 Estimates of modelled soil loss and sediment yield for Irish catchments.

\begin{tabular}{llllrrrl}
\hline Catchment & $\mathrm{SL}_{1}$ & $\mathrm{SL}_{2}$ & $\mathrm{SY}_{\mathrm{m} 1}$ & \% diff & $\mathrm{SY}_{\mathrm{m} 2}$ & \% diff & $\mathrm{SY}_{\mathrm{obs}}$ \\
\hline Dunleer (year 1) & 1.01 & 1.49 & 0.362 & +142 & 0.535 & +257 & 0.15 \\
Dunleer (year 2) & 0.81 & 1.20 & 0.293 & +117 & 0.433 & +220 & 0.135 \\
Castledockrell (year 1) & 7.40 & 9.87 & 2.590 & +1363 & 3.453 & +1851 & 0.177 \\
Castledockrell (year 2) & 1.95 & 2.60 & 0.683 & +2104 & 0.911 & +2839 & 0.031 \\
Dripsey (year 1) & 7.56 & 6.80 & 2.572 & +1497 & 2.310 & +1335 & 0.161 \\
Dripsey (year 2) & 4.28 & 3.84 & 1.455 & +1385 & 1.307 & +1234 & 0.098 \\
Mattock & 0.54 & 0.61 & $\mathbf{0 . 1 7 3}$ & -61 & $\mathbf{0 . 1 9 6}$ & -55 & 0.44 \\
Clarianna & 0.64 & 0.27 & 0.198 & +133 & $\mathbf{0 . 0 8 2}$ & -3 & 0.085 \\
The Oona (year 1) & 0.47 & - & $\mathbf{0 . 1 2 8}$ & -56 & - & - & 0.29 \\
The Oona (year 2) & 0.71 & - & $\mathbf{0 . 1 9 3}$ & -53 & - & - & 0.41 \\
Owenabue & 4.39 & 5.02 & 1.186 & +363 & 1.355 & +429 & 0.256 \\
Bandon & 2.98 & 2.34 & 0.655 & +352 & 0.514 & +255 & 0.142 \\
\hline
\end{tabular}

SL - average soil loss (tonnes ha- ${ }^{-1}$ year-1), $\mathrm{SY}_{\mathrm{m}}$ - modelled sediment yield estimated (tonnes ha-1 year $^{-1}$ ) (Note: suffix 1 = values estimated with $L S_{1}$, suffix 2 = values estimated with $L S_{2}, \mathrm{SY}_{\mathrm{obs}}-$ observed sediment yield (tonnes ha $^{-1}$ year ${ }^{-1}$ ), \% diff = percentage difference between modelled and observed values; Bold values indicate positive estimates of sediment yield in comparison to the observed values 


\section{Model uncertainties}

The $R$ factor is the only element in RUSLE that can differentiate between different measured values for dry and wet years (since no major land-use change was recorded). Percentage change in calculated $R$ factors between years one and two corresponds well to a percentage change in measured sediment yields between these years. Thus, it can be concluded that calculated $R$ factors represent the erosive nature of events reasonably well. However, some uncertainty is introduced when data for the nearest synoptic station (with high resolution record) is used as opposed to original data for the catchment.

The soil erodibility factor has to be further validated against national soil datasets. The crop cover factor can also be improved by considering different values for pastures depending on livestock densities and increased values for winter crops.

Comparison of $L S$ factors calculated with the two methods indicates potential for the use of catchment descriptors in the estimation of this factor. Further improvement of the slope-drainage density method may include different slope classes instead of lumped mean values. Moreover, the small percentage of very high cell grid values in the GIS LS 2 raster maps resulted in high standard deviation values (7.84-123.4 between study catchments), which may indicate that the average value does not represent this factor fully. Calculation of this factor needs to be investigated further with the possibility of including different methods for LS estimation.

Although SDR estimated with the drainage area method is convenient to use, adaptation of this method at a small sub-basin scale will assume a delivery ratio of about $35 \%$, which may be overestimating sediment transfer from the catchments. A different approach incorporating other catchment characteristics needs to be investigated for further improvement of this factor.

Finally, it should be noted that the RUSLE model only predicts surface soil erosion and does not takes into account channel bank erosion, which can be a very important sediment source in both lowland and upland catchments (e.g. Lawler, 2008). Walling (2005) reported a 5-48\% contribution of channel bank erosion to sediment yields for 34 UK catchments, and contributions as high as 66-89\% were reported in the Gelbæk catchment in Denmark (Kronvang et al. 1997). Underestimated sediment yield values in this study may therefore be improved with the inclusion of a bank erosion factor, although this would exacerbate the already overestimated values that were observed in the majority of modelled sediment yields.

\section{CONCLUSIONS}

Models can be used to identify areas with a relatively high risk of contributing sediment pollution to rivers. Catchment scientists can use this information to understand sediment generation and delivery processes, target mitigation measures and enforce agricultural policies. This study assesses the suitability of RUSLE and SDR for predicting high risk areas for sediment mobilisation and delivery at the basin scale.

A comparison of the RUSLE model with observed values contributes to a better understanding of the mechanisms leading to catchment soil loss and also constitutes an important step towards the construction of a national sediment assessment tool. The methods for determining RUSLE factors are under review as the model is currently overestimating sediment yield in most catchments. The slope-drainage density method for the $L S$ factor estimation shows promising results, and although this approach overestimates sediment yield for some catchments, it does provide a better estimation for some of the catchments than the UCA method.

A very good model fit for Clarianna catchment and positive results for the Oona and Mattock indicate the potential of the RUSLE model as an assessment tool. However, further work is required to improve the RUSLE factor estimations and appropriate SDR measures for Irish conditions.

Acknowledgements Funding for this research was provided by the Environment Protection Agency, Ireland under the EPA STRIVE Programme (SILTFLUX 2010-W-LS-4). The authors would like to acknowledge the support provided by Des Walling, Steve Omerod, John Quinton and Martin McGarrigle on the SILTFLUX project. 


\section{REFERENCES}

Bakker, M. M., et al. (2008) The response of soil erosion and sediment export to land-use change in four areas of Europe: The importance of landscape pattern. Geomorphology 98, 213-226.

Bilotta, G. S. \& Brazier, R. E. (2008) Understanding the influence of suspended solids on water quality and aquatic biota. Water Res. 42, 2849-2861.

Borah, D. K. \& Bera, M. (2003) Watershed-scale hydrologic and nonpoint-source pollution models: review of mathematical bases. T. ASAE 46(6), 1553-1566.

Collins, A. L., et al. (2011) Sediment targets for informing river catchment management: international experience and prospects. Hydrol. Proceses 25, 2112-2129.

Harrington, S. T. \& Harrington, J. R. (2013) An assessment of the suspended sediment rating curve approach for load estimation on the Rivers Bandon and Owenabue, Ireland. Geomorphology 185, 27-38.

He, Y. (2010) Estimating soil erosion and sediment yield with GIS, RUSLE and SEDD: a case study in Ireland. Masters Thesis, School of Geography and Archaeology, National University of Ireland, Galway, Ireland.

Heywood, M.J.T. \& Walling, D.E. (2007) The sedimentation of salmonid spawning gravels in the Hampshire Avon catchment, UK: implications for the dissolved oxygen content of intragravel water and embryo survival. Hydrol. Processes $21,770-88$.

Jones, J. I., et al. (2012) The impact of fine sediment on macro-invertebrates. River Res. Appl. 28(8), $1055-1071$.

Kemp, P., et al. (2011) The impacts of fine sediment on riverine fish. Hydrol. Processes 25, 1800-1821.

Kiely, G., et al. (2007) Eutrophication from agricultural sources (Phosphorus and Nitrogen). Sub-project Soil and Phosphorus: Catchment Studies. EPA, Ireland (Ref. 2000-LS-2.1.1a-M1).

Kinnell, P.I.A. (2010) Event soil loss, runoff and the universal soil loss equation family of models: a review. J. Hydrol. 385, 384-397.

Kronvang, B., Laubel, A. \& Grant, R. (1997) Suspended sediment and particulate phosphorus transport and delivery pathways in an arable catchment, Gelbæk stream, Denmark. Hydrol. Processes 11, 627-642.

Lawler, D.M. (2008) Advances in the continuous monitoring of erosion and deposition dynamics: Developments and applications of the new PEEP-3T system. Geomorphology 93, 17-39.

Lawler, D.M., et al. (2006) Turbidity dynamics and hysteresis patterns during spring storm events in an urban headwater system: the Upper Tame, West Midlands, UK. Sci. Total Environ. 360, 109-126.

Lawler, D.M., et al. (2009) Geomorphology and sediments of the hyporheic zone. In: The Hyporheic Handbook: A Handbook on the Groundwater-Surface Water Interface and Hyporheic Zone for Environment Managers, Environment Agency Integrated Catchment Science Programme, Science Report: SC050070, Chapter 3, 16-47.

May, L. \& Place, C.J. (2005). A GIS-based model of soil erosion and transport. Freshwater Forum 23, 48-61.

May, L., et al. (2005) Modelling soil erosion and transport in the Burrishoole catchment, Newport, Co. Mayo, Ireland. Freshwater Forum 23, 139-154.

Melland, A.R., et al., (2012) Stream water quality in intensive cereal cropping catchments with regulated nutrient management. Environ. Sci. Policy 24, 58-70.

Meusburger, K., et al. (2012) Spatial and temporal variability of rainfall erosivity factor for Switzerland. Hydrol. Earth Syst. Sci. 16, 167-177.

Mitasova, H., et al. (1996) Modeling topographic potential for erosion and deposition using GIS, Int. J. Geogr. Inf. Sci. 10(5), 629-641.

Mitasova H., et al. (2010) Using soil erosion modelling for improved conservation planning: A GIS-based Tutorial. Geographic Modelling Systems Lab, UIUC, Available from: http://www4.ncsu.edu/ hmitaso/gmslab/reports/CerlErosionTutorial/ denix/denixstart.html (20th February 2014)

Moore, I.D. \& Wilson, J.P. (1992) Length-slope factors for the Revised Universal Soil Loss Equation: Simplified method of estimation. J. Soil Water Conserv. 47, 423-428.

NPWS (2008) The Status of EU Protected Habitats and Species in Ireland. Conservation Status in Ireland of Habitats and Species listed in the European Council Directive on the Conservation of Habitats, Flora and Fauna 92/43/EEC. National Parks and Wildlife Service, Department of the Environment, Heritage and Local Government, Ireland.

Owens, P.N., et al. (2001) Downstream changes in the transport and storage of sediment associated contaminants (P, Cr and PCBs) in agricultural and industrialised drainage basins. Sci. Total Environ. 266, 177-186.

Panagos, P., et al. (2012) European Soil Data Centre: Response to European policy support and public data requirements. Land Use Policy 29 (2), 329-338, doi:10.1016/j.landusepol.2011.07.003.

Panagos, P., et al. (2014) Soil erodibility in Europe: A high-resolution dataset based on LUCAS. Sci. Total Environ. 479-480, $189-200$.

Parsons, A. J., et al. (2008) Is sediment delivery a fallacy? Reply. Earth Surf. Land 33, 1630-1631.

Pham, T. N., et al. (2001) Application of RUSLE Model on Global Soil Erosion Estimate. A. J. Hydraul. Eng-JSCE 45, 811-816.

Ranzi, R., Le, T. H., \& Rulli, M. C., (2012) A RUSLE approach to model suspended sediment load in the Lo River (Vietnam): Effects of reservoirs and land use changes, J. Hydrol. 422-423, 17-29.

Renard, K.G., et al. (1997) Predicting Soil erosion by water: a guide to conservation planning with the Revised Universal Soil Loss Equation. US Department of Agriculture, Agricultural Research Services, Agricultural Handbook 703 . USA.

Thompson, J., et al. (2014) Assessing suspended sediment dynamics in relation to ecological thresholds and sampling strategies in two Irish headwater catchments. Sci. Total Environ. 468-469, 345-357.

Vanmaercke, M., et al. (2011) Sediment yield in Europe: Spatial patterns and scale dependency. Geomorphology 130, $142-161$.

Vanoni, V.A. (ed.). (1975) Sedimentation Engineering, ASCE Manuals and Reports on Engineering Practice No.54. American Society of Civil Engineers, NewYork.

Walling, D. E. (1983) The sediment delivery problem. J. Hydrol. 65, 209-237.

Walling, D. E. (2005) Tracing suspended sediment sources in catchments and river systems. Sci. Total Environ. 344, $159-184$.

Walsh, R. P. D. \& Lawler, D. M., (1981) Rainfall seasonality: description, spatial patterns and change through time. Weather 36, 201-208.

Wischmeier, W. H., \& Smith, D. D. (1978) Predicting rainfall erosion losses, a guide to conservation planning. Agriculture Handbook No. 537. US Department of Agriculture, Washington DC. 